\title{
Ex situ bioremediation method for the treatment of groundwater contaminated with PAHs
}

\author{
M. Höckenreiner $\cdot$ H. Neugebauer • \\ L. Elango
}

Received: 28 March 2013/Revised: 26 August 2013/Accepted: 4 November 2013/Published online: 5 December 2013

(C) Islamic Azad University (IAU) 2013

\begin{abstract}
The present study was carried out with the objective of integrating physical and biological methods for the treatment of polycyclic aromatic hydrocarbons (PAHs)-contaminated groundwater and to assess its efficiency. The aquifer in Kirchseeon region, Germany, is contaminated with PAHs due to product loss of tar oil which was used in large amounts for treating the railway sleepers produced in this area. Six pumping wells, two recharge wells and fifteen observation wells were installed for this study as a part of the ex situ biodegradation treatment plant. Zoogloea, Leptothrix, Sphingomonas, Novosphingobium and Comamonadaceae were the indigenous bacteria that facilitated degradation of the PAHs. In the bioreactors, $95 \%$ of naphthalene and methylnaphthalene and $90 \%$ of total PAHs were removed. During this remediation process, $700,000 \mathrm{~m}^{3}$ of PAHs-contaminated groundwater was purified to almost drinking water quality. Also, $7,000 \mathrm{~kg}$ of dense non-aqueous phase liquid (DNAPL) and $950 \mathrm{~kg}$ of PAHs were removed from the pumped groundwater. The remediated groundwater is recharged back into the aquifer through two recharge wells located $600 \mathrm{~m}$ from the study site. The observation wells show a decrease in contamination of up to $95 \%$. Thus, this
\end{abstract}

M. Höckenreiner

BfU Büro für Umweltfragen $\mathrm{GmbH}$, Starnberger Strasse 22, 82131 Gauting, Germany

H. Neugebauer

DB Netz AG, Regionale Instandsetzung Süd, I.NP-S-R (S), Richelstraße 3, 80634 Munich, Germany

L. Elango $(\square)$

Department of Geology, Anna University,

Chennai 600025, India

e-mail: elango34@hotmail.com field scale study showed that using indigenous bacteria to remediate PAHs-contaminated groundwater is a viable option.

Keywords Hydrogeology - Dense non-aqueous phase liquid · Light non-aqueous phase liquid . Tar oil . Indigenous bacteria - Activated carbon - Kirchseeon . Germany

\section{Introduction}

Environmental problems, which arise from industrial contamination, have been recognized to be a major problem for public health and urban development. In order to overcome this problem, industrialized countries have enforced laws so that the design of modern industrial plants minimizes the risk of possible environmental damage. However, for legacy contamination already in the environment, these sites must be remediated until a specified goal is achieved. The management problems arising from environmental contamination require characterization of polluted zones and the development of suitable and costeffective remedial measures. Polycyclic aromatic hydrocarbons (PAHs) are one class of important environmental pollutants which are of concern because some of them are carcinogenic and mutagenic (e.g. Menzie and Potokib 1992; Limam and Driss 2013). PAHs are widely present in the environment and can be formed during the burning of coal, gas, wood, tobacco and other organic substances. They are also present in tars, crude oil and petroleum products. The incomplete combustion (pyrolysis) of fossil fuels/organic materials, as well as natural processes such as carbonization (pyrosynthesis), may lead to the release of effluents containing PAHs that enter streams, rivers and 
groundwater. Combustion also leads to the release of PAHs into the atmosphere which may settle onto the land surface. Reactions of PAHs with other atmospheric pollutants, namely $\mathrm{NO}_{\mathrm{x}}, \mathrm{SO}_{2}, \mathrm{O}_{2}$, etc., may form hetero-PAHs. The carcinogenicity and mutagenicity of many of these heteroPAHs compounds are greater than their parent compounds (Pandey et al. 1999). The detection, identification, quantification and monitoring the presence of these substances in groundwater and soil are important due to their detrimental effects and these environmental contaminants have been studied extensively (e.g. Brassington 2013; Han et al. 2013; Commendatore et al. 2012; Liang et al. 2012; Thavamani et al. 2012; Zhang et al. 2012; Li et al. 2010; Fengpeng et al. 2009; Kordybach et al. 2009; Zhu et al. 2008; Atanassova and Brummer 2004; Chen et al. 2004). The various PAHs compounds in groundwater occur primarily in two forms, directly dissolved in the water or in the form of dense non-aqueous phase liquid (DNAPL).

Remediation of PAHs-contaminated groundwater may be carried out by physical, chemical or biological methods. Physical method involves removal of PAHs in the form of DNAPL by density separation, while chemical method involves ozone treatment and use of Fenton's reagent for enhancing PAHs degradation. Generally, dissolved PAHs are removed from groundwater by adsorption onto activated carbon, although other materials have also proven to be suitable (e.g., Valderrama et al. 2009). Biological processes produce comparatively less secondary waste thus reducing the burden of disposal of contaminated material in contrast to physical and chemical processes. Bioremediation is the use of biological processes to accelerate the removal of contaminants from the environment (IMO 2004). In places of contamination, certain microbes thrive by their natural ability to utilize the contaminant as a source of energy. These microbes will often serve as the optimal organism to remediate the contaminant from a particular area, as they have adapted specifically to the site conditions and contaminants. Numerous bacterial strains capable of existing in soils contaminated with PAHs have been isolated and characterized (Zhang et al. 2004; Abd-Elsalam et al. 2009; Mao et al. 2012; Muangchinda et al. 2013). Several researchers have used the help of microbes to remediate diesel oil contaminated soil (Wang et al. 1990; Penet et al. 2004; Chagas-Spinelli et al. 2012; Silva-Castro et al. 2013; Vázquez et al. 2013) and manufactured gas plant site soil (Hawthorne and Grabanski, 2000). Comparison of various field and laboratory methods in bioremediation process of PAHs-contaminated soil has also been carried out by many researchers (Lors et al. 2012; Moscoso et al. 2012; Lladó et al. 2013).

In general, DNAPL is present as a separate water immiscible phase and has very limited surface available to reactions. Biological treatment is therefore more applicable for the dissolved PAHs, whereas DNAPL has to be either pumped directly from the aquifer or removed by excavation. Therefore, only a few specific treatment methods have shown to successfully remediate DNAPL in groundwater. For example, DNAPL contaminated soil and groundwater have been successfully treated through biodegradation by providing optimized temperature conditions (Trably and Platureau 2006), using specific microorganisms (Harayama 1997; Li et al. 2008) and with controlled oxygen activity for aerobic process (Haritash and Kaushik 2009). Long-term attenuation of subsurface contaminants by microbial composition in a coal tar contaminated site was studied by Yagi et al. (2010). Neuhauser et al. (2009) have monitored PAHs in groundwater of a manufactured gas plant and their natural attenuation.

The present study describes the remediation of PAHs impacted groundwater of a major railway sleeper impregnation factory in Kirchseeon region, near Munich, Germany, which existed between 1869 and 1959. The location of the study area with geology (after Bayerisches Geologisches Landesamt (1994)) of its surroundings is shown in Fig. 1. The factory in this area had used a large amount of tar oil for treating the railway sleepers produced. Tar oil used throughout the period of operation was a mixture of numerous PAH compounds and material handling over the nearly 100-year operational period led to contamination of groundwater of this region. Some preliminary investigations were carried out during the late 1960s. These investigations revealed that the groundwater was contaminated by PAHs. In awareness of commensurability, it has to be remediated even if the contamination plume may not migrate further downstream causing problems for any direct use of the groundwater. In the case presented here, the state authorities had determined that the magnitude with which groundwater $\mathrm{PAH}$ concentrations exceeded regulatory threshold values was large enough to commence a major remediation project. This study was carried out with the objective of integrating biological and physical methods such as separation and sorption for the treatment of PAHs-contaminated groundwater and to assess its efficiency. The ex situ process of treatment of water contaminated by DNAPL through physical separation and then removing the diluted $\mathrm{PAH}$ compounds by adsorption with activated carbon and/or by biological methods is very much in practice. However, to improve the efficiency of these techniques, DNAPL which is likely to be present at the bottom of the aquifer can be pumped out separately. In fact, the combination of pumping the PAHs-contaminated groundwater and DNAPL separately will work better for microbiological degradation of PAHs. The main feature of this study shows that the combination of biodegradation of diluted PAH compounds and the immediate use of the sorption capacity of the growing biomass to filter the remnant compounds is highly effective. This reduces the use of activated carbon than in other examples to reach 
Fig. 1 Location of the study area and geology of its surroundings

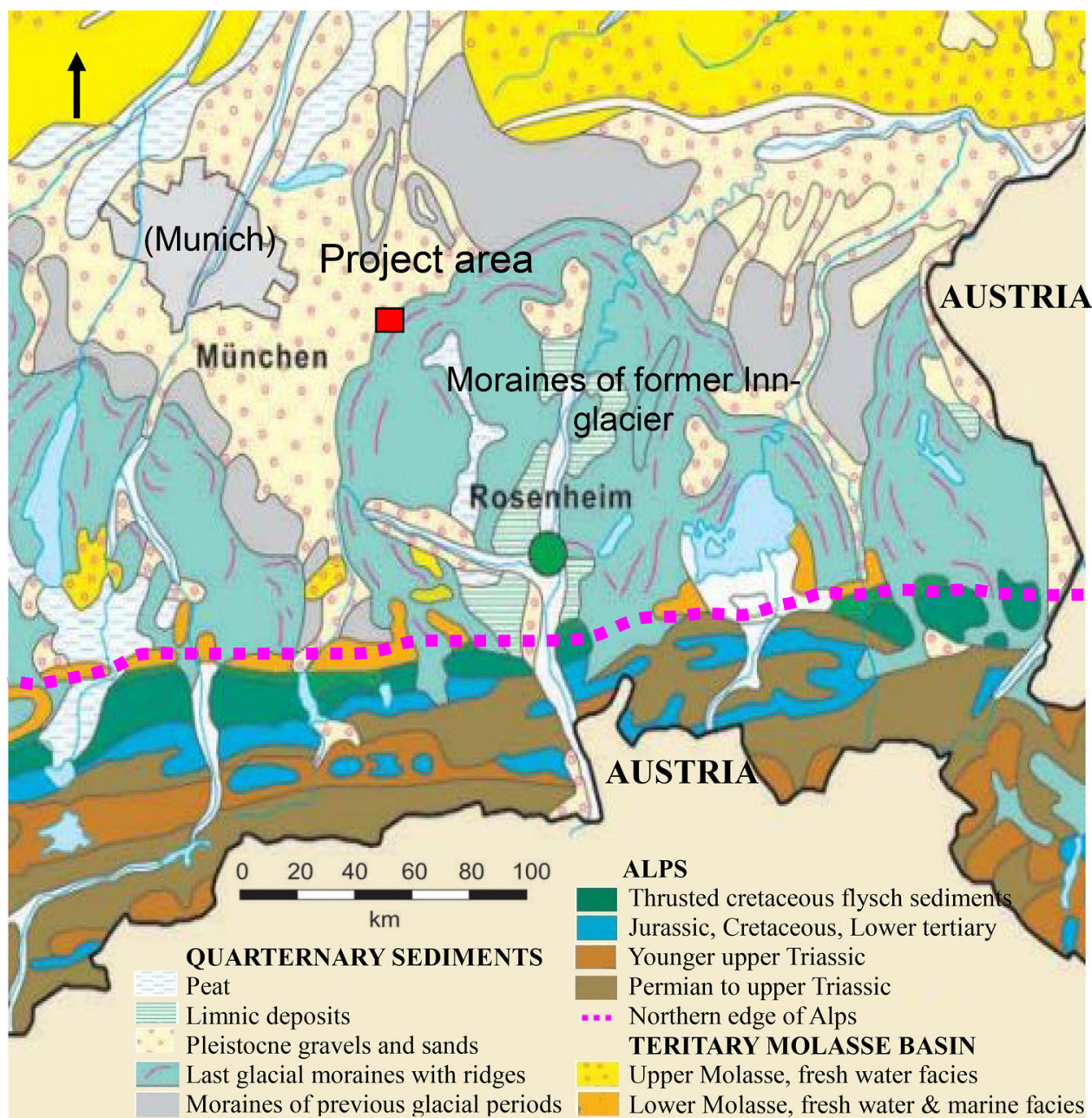

After Bayerisches Geologisches Landesamt (1994) water purity as nearly as drinking water. Thus, a successful implementation of the effectiveness and advantages of a pump and treatment facility to remediate PAHs-contaminated groundwater is presented here.

\section{Study area}

The Kirchseeon region is located $15 \mathrm{~km}$ east of Munich, Germany (Fig. 1). The atmospheric average day temperature generally varies from $-2{ }^{\circ} \mathrm{C}$ (January) to $+18{ }^{\circ} \mathrm{C}$ (July). The annual average precipitation is about $900 \mathrm{~mm}$. Snowfall in the region generally occurs between November and March. The region gently slopes towards north-western direction. There is no surface drainage in the form of streams. This region was traditionally used mostly for dairy farming and local timber production. However, eventually the region turned into a distant suburb of Munich, and it has undergone rapid development due to the establishment of a railway sleeper impregnation factory.
Geology and hydrogeology

Geologically the project area is situated at the north-western rim of the former Inn-glacier (last glacial maximum). The end morraine ridge from south-west to north-east has been cut through by melting waters of the ice age glacier leaving behind a gap in the ridge (Fig. 1). Kirchseeon is situated in this valley-like position. The Upper Tertiary sediments (Miocene) found at the depth of $40 \mathrm{~m}$ below surface, called Upper Freshwater Molasse ("Obere Süßwassermolasse"), represented by dense silty clays to clay-rich sandy silts function as an aquiclude. This is overlain by a sequence of Quaternary sandy gravels up to ground surface with a thickness of approximately $40 \mathrm{~m}$. The quaternary aquifer consists mainly of sandy gravels with hydraulic conductivity values between $1 \times 10^{-3} \mathrm{~m} / \mathrm{s}$ and $1 \times 10^{-4} \mathrm{~m} / \mathrm{s}$, and it occurs in an unconfined condition (Fig. 2). The groundwater flow direction is roughly towards NE, and the saturated thickness is about $5 \mathrm{~m}$. This 
Fig. 2 SW-NE cross section of the project area (after GEO-data 2009)

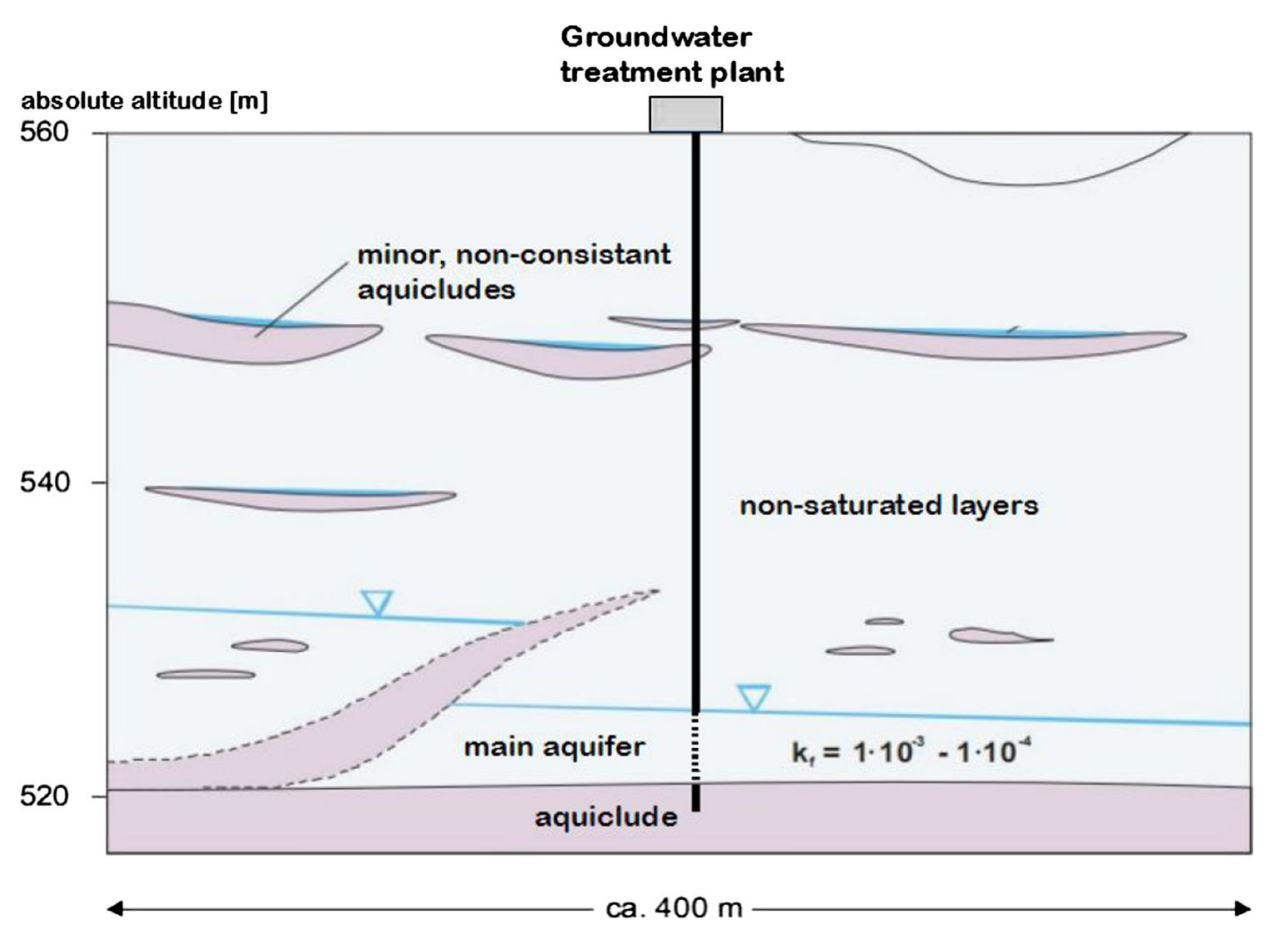

sequence has intercalations of silty lenses, with higher frequency at two levels, one at around $22 \mathrm{~m}$ below surface and another at around 10-12 $\mathrm{m}$ below the surface. These lenses do not function as confining layers but they form perched aquifers.

\section{Materials and methods}

A detailed investigation (1998-2001) was carried out to assess the extent of groundwater contamination. Later a pilot treatment plant (2002-2004) was used to assess the feasibility strategies for groundwater remediation. Subsequently, in August 2005, the treatment method that was likely to be most effective for treating groundwater was selected. The hydrogeological investigation assisted in determining the number of wells and their location to pump PAHs-contaminated groundwater and recharge the treated water. This resulted in designing a gallery of six wells in the downstream side (FB1 to FB6 in Fig. 3) of the groundwater-contaminated zone and two wells for recharging (VB1 and VB2 in Fig. 3) the treated water. The delineation of the unsaturated and the saturated zones containing tar oil was difficult due to the presence of clay and silt intercalations. These intercalations were directing the tar oil to move laterally and then vertically to the saturated zone. Based on the long-term observation of levels of contamination and groundwater modelling, the exact locations of the pumping and recharge wells were selected.
Also, fifteen observation well locations were identified to properly monitor and estimate the efficiency of the remediation plant (Fig. 3). These wells were drilled up to a depth of the main aquiclude located between 40 and $48 \mathrm{~m}$ below ground level. Each pumping well was installed with two discharge pipes with independent pumps to pump groundwater and DNAPL separately. All groundwater samples were collected during the ongoing remediation. These water samples were collected in 1-1 brown glasses by filling sample up to the rim for analysis on PAHs. All samples were stored in a cold box immediately after sampling and subsequently (within few hours) transported to the laboratory for analysis. Analysis on PAHs and naphthalenes was carried out according to E DIN 38407-F39, GC-MS. Isotopic analysis on ${ }^{13} \mathrm{C}$ was carried out by Hydroisotop $\mathrm{GmbH}$, Germany, using purge and trap, GC-C-IRMS-MS. As a measure of the isotopic content, the relative difference of the isotope ratio of the sample with respect to the isotope ratio of laboratory standards is given in \%o ( $\delta$ values). Here, the international accepted standard VPBD (Vienna Pee-Dee-Belemnite) is used $\left({ }^{12} \mathrm{C} /{ }^{13} \mathrm{C}=0.0112372\right)$. DIN EN ISO 11885 (E22) ICPOES methods were used for the measurement of $\mathrm{Fe}$ and $\mathrm{Mn}$. The activated carbon (trade name Aqua S 830X) is steam-activated, based on selected mineral coal. It has an iodine No. of about $950 \mathrm{mg} \mathrm{I} / \mathrm{g}$.

To analyze the composition of the microbial community, genomic DNA was extracted from the solid samples using the Ultra Clean Soil DNA Kit Mega Prep (MOBIO 
Fig. 3 Groundwater flow lines around six pumping wells (bottom) and the two infiltration wells (top) deduced by groundwater modelling (map detail from GEO-data 2003)
Fig. 4 Schematic view of the remediation plant (after GEOdata 2009)

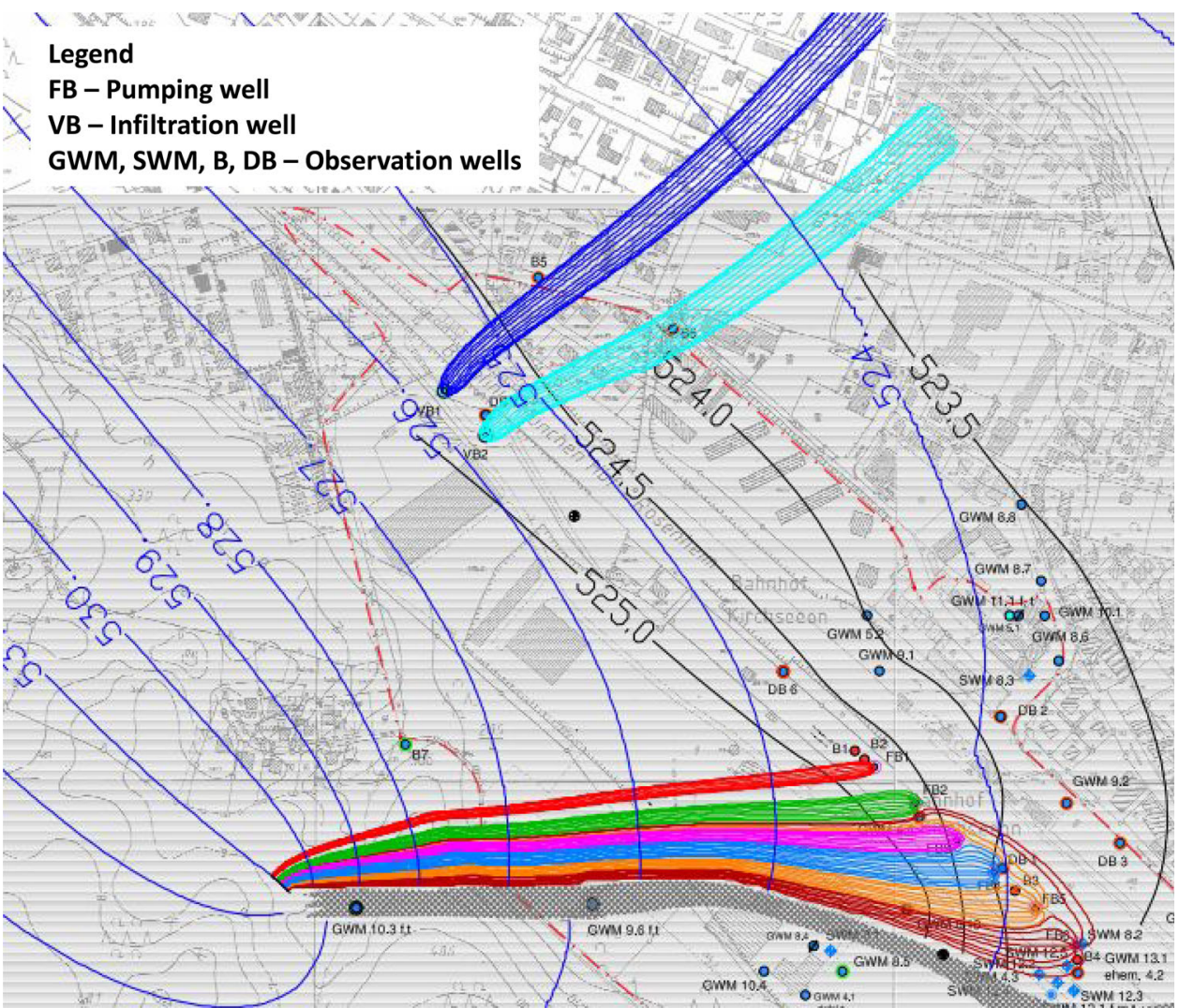

GEO data

Die Bahn DB

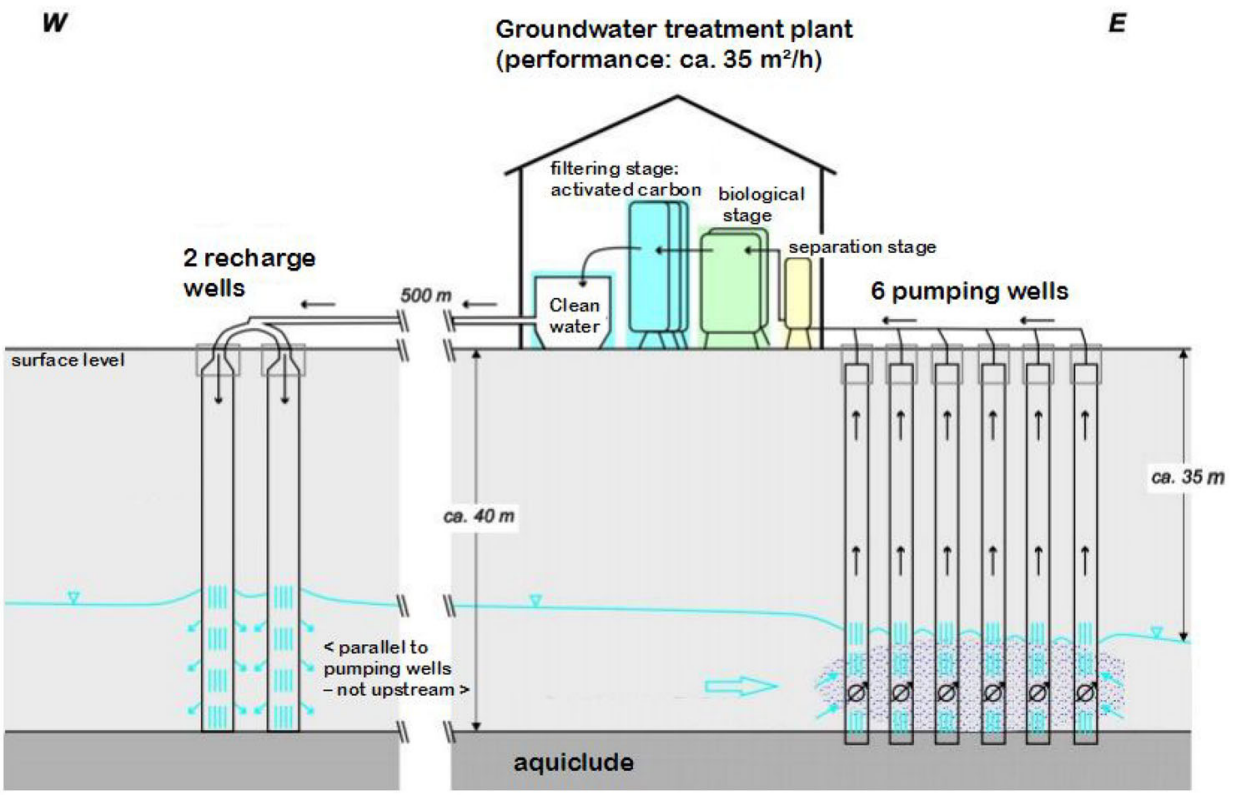

Laboratories Inc., USA). After determination of the DNA concentration in the extracts obtained, bacterial 16S rRNA gene sequences with the oligonucleotide primers GC341f and 907r (Muyzer et al. 1995) and eukaryotic 18S rRNA genes with the primers Euk1A and Euk 516R GC (Dìez et al. 2001) were amplified by polymerase chain reaction (PCR). The amplification products were loaded on a denaturing gradient gel electrophoresis (DGGE) gel and 
separated according to their melting behaviour. For DGGE, a $6 \%$ polyacrylamide gel with a gradient of urea and formamide was used. The nucleotide sequences were compared with the sequences present in the GenBank database (NIH, Washington, USA) using the BLASTN Software. Subsequently, a phylogenetic analysis was carried out after alignment of the sequences in ClustalX by means of the maximum likelihood method using the software package Phylip.

The total discharge of groundwater from the pumping wells was around $25-35 \mathrm{~m}^{3} / \mathrm{h}$ which resulted in changing the hydraulic gradient. The reversal of hydraulic gradient induces DNAPL movement towards the well over the surface of the aquiclude. DNAPL is then pumped by separate pumps from the bottom of the well as these pumps are fixed below the groundwater pump. As the flow rate of DNAPL is very low (between 0.1 and 5 1/day), the pumps are operated at frequent intervals. The DNAPL pumped is collected in containers and sent to other agencies for thermal waste treatment (Fig. 4).

\section{Design of the treatment plant}

Bioremediation of PAHs may be applied either in situ or ex situ. In situ method typically involves construction of barriers (biological ones or such filled with activated carbon) along the direction of groundwater flow, so that when the groundwater passes through the bio-barrier from the upgradient side, the plume is purified before discharging on the downstream side. But this method is expensive because of the installation of bio-barriers which in this case might have been built to a design depth of about $40 \mathrm{~m}$. Hence, in this case, it was determined to be more economical to employ an ex situ remediation process which involves pumping of contaminated groundwater and passing them through bioreactors with indigenous microorganisms that are capable of degrading PAHs. Some of the bioreactor methods available include on-site land farming and composting, aerobic and anaerobic treatment and phytoremediation (Gan et al. 2009). Seo et al. (2007) used organic mulch as an alternative supporting material in permeable, biological, barrier walls to prevent migration of PAHs. Guerin (2002) tried to remediate groundwater from a coal tar contaminated site by using two bioreactor configurations, a submerged fixed film reactor (SFFR) and a fluidized bed bioreactor (FBR). This study concluded that although both reactors were found to be effective, SFFR provides a simpler design and operation.

Another design specification to consider is the type(s) of microorganisms to be used in the bioreactors. Bioremediation of naphthalene in water by Sphingomonas paucimobilis was identified by Miguel et al. (2009). In situ bioremediation by injection of hydrogen peroxide, an oleophilic fertilizer, and a surfactant was practised by Menendez-Vega et al. (2007) which was found to be effective in soil and groundwater polluted with hydrocarbons. Though there are several microorganisms capable of degrading PAHs, using the native microbes is the safest and cost-effective method. Considering this, the treatment plant was designed where the PAHs-contaminated groundwater was treated in several stages: separation, biological treatment and sorption stages as described below.

\section{Results and discussion}

\section{Separation stage}

Although in this case DNAPL is pumped separately, small amounts of DNAPL still remain in groundwater and are emulsified in the submersible pump. Also small amounts of light non-aqueous phase liquid (LNAPL) are present in the pumped water. Hence, it is necessary to remove the DNAPL and LNAPL from the groundwater pumped for treatment. In this case, a LNAPL and DNAPL separator with coalescence stage was used; especially, wells FB3 and FB5 (Fig. 3) show abundant microbiology already in the pumped water. This biomass also accumulates partly in the separator. Possibly in these two wells, bacteria find more ideal conditions than in other wells as the water here still contains small amounts of oxygen (about $2 \mathrm{mg} / \mathrm{l}$ ) and perhaps PAHs contents for the bacteria are not at toxic concentrations (mean value of more than 70 analysis on PAH contents of wells FB3, FB4, FB5 and FB6 are 383; 4,$770 ; 670$ and $1,680 \mu \mathrm{g} / \mathrm{l}$, respectively). Due to the mixing of the waters and oxygen enrichment, biological degradation is possible even with more toxic concentration as in wells FB4 and FB6.

\section{Biological treatment stage}

In the second stage, pressurized ambient air is sent into the water to raise the oxygen concentration from less than $1-10 \mathrm{mg} / \mathrm{l}$ (max. saturation). The oxygen enriched water is then pumped into bioreactors, where more than $90 \%$ of the PAHs contamination is removed both by microbiological and physical effects of the growing biomass (Fig. 5). With respect to the concentration of naphthalene and methylnaphthalene, the reduction is more than $95 \%$ of the original influent concentrations. In the range of the typical PAHs, these two compounds have the smallest molecules and are thus physically more agile as well as chemically more reactive for biodegradation. Contaminated groundwater of Kirchseeon contains naphthalene and methylnaphthalene up to $50 \%$ of the total PAHs concentration, 
Fig. 5 PAHs content of groundwater before and after passing through the bioreactor

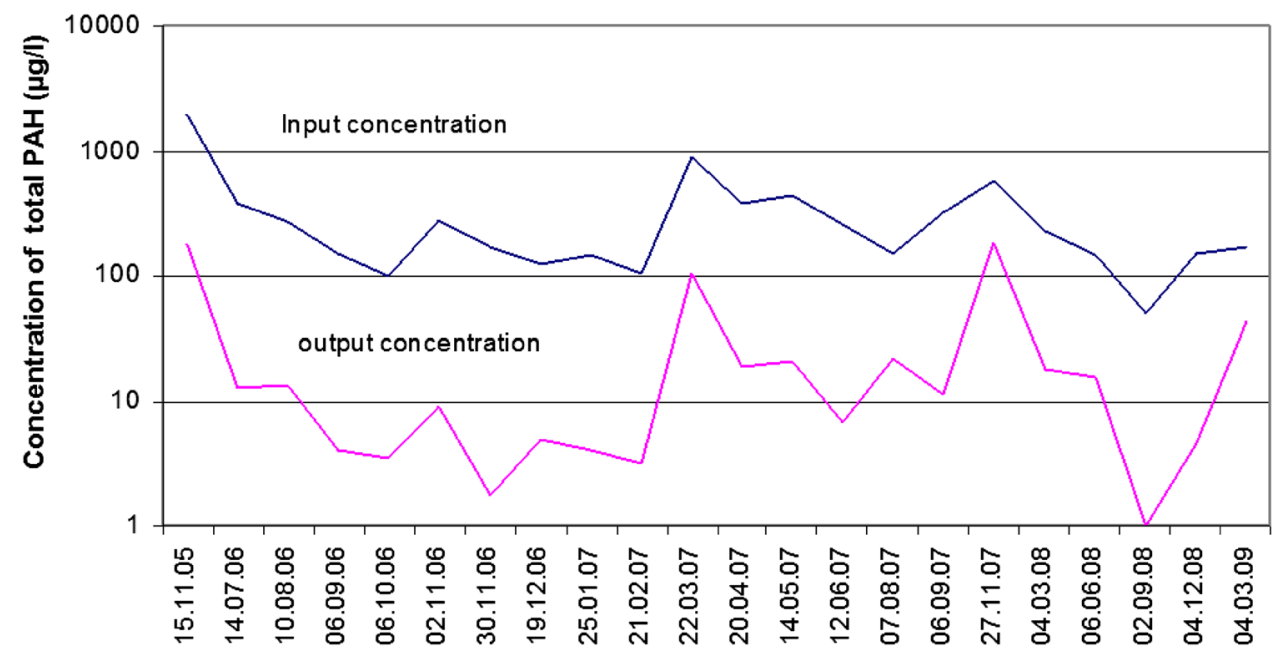

Table 1 Average concentration of selected PAHs before and after passing through the bioreactor

$$
\text { Influent Effluent Reduction }
$$$$
(\%)
$$

\begin{tabular}{lccc}
\hline $\begin{array}{l}\text { Total sum PAH }(\mathrm{EPA})+\text { methyl- } \\
\text { naphthalenes1,2 }(\mu \mathrm{g} / \mathrm{l})\end{array}$ & 339.3 & 32.6 & 90 \\
Naphthalene $(\mu \mathrm{g} / \mathrm{l})$ & 41.5 & 1.4 & 97 \\
1-Methylnaphthalene $(\mu \mathrm{g} / \mathrm{l})$ & 42.2 & 3.0 & 93 \\
2-Methylnaphthalene $(\mu \mathrm{g} / \mathrm{l})$ & 13.1 & 2.7 & 79 \\
Phenanthrene $(\mu \mathrm{g} / \mathrm{l})$ & 71.3 & 2.9 & 96 \\
Fluoranthene $(\mu \mathrm{g} / \mathrm{l})$ & 20.4 & 5.2 & 75 \\
\hline
\end{tabular}

i.e. the total concentration of representative PAHs compounds according to EPA. The concentration of few PAHs before passing the bioreactor (influent) and after passing the bioreactor (effluent) is given in Table 1.

The bioreactor contains mainly sand and anthracite layers. The microbiota degrading PAHs are autochthonous. The bioreactors are automatically backwashed in empirically determined intervals which were estimated considering the pressure-trend of the biofilters. The sludge from the bioreactors which contains PAHs and abundant microorganisms is accumulated in a sludge tank. Periodically the sludge is removed from the sludge tank by a suction vehicle and deposited in an approved landfill.

For determining the processes leading to the significant reduction of PAHs contents in the bioreactors, the accumulated sludge was investigated in detail. In a first step, dominating bacteria species and eukaryotes were identified. Over 25 different 16S rRNA gene sequences of bacteria as well as 4 different $18 \mathrm{~S}$ rRNA gene sequences derived from eukaryotes were recognized. The identified bacteria were mainly, typical slime-forming water and sewage bacteria (genera Zoogloea, Leptothrix) and typical aromatic hydrocarbon decomposing bacteria (genera Sphingomonas,
Novosphingobium and Comamonadaceae). Eukaryotic protozoa were mainly amoebas and heliozoans. There is no clear evidence of the presence of fungi neither by microscopic investigation nor by the molecular biology study.

In a second step, PAHs mass balancing was carried out on the accumulated sludge (see Table 2). As the sludge was extracted discontinuously by a suction vehicle, one accumulation period before the next sludge removal was studied intensively. This sludge layer had formed in about 5 months. From the chemical data and flow rates of pumped water, it was calculated that $16 \mathrm{~kg}$ of dissolved PAHs was removed in the bioreactors during sludge accumulation. Just before extraction, three representative samples of the accumulated sludge were taken and analyzed for their PAHs content. The PAHs content gave a mean value of $310 \mathrm{mg} / \mathrm{kg}$, which based on the mass of the accumulated sludge equals a total PAHs content of $820 \mathrm{~g}$ which was removed by physical sorption effects. Most likely PAHs adsorb on grain surfaces possibly with the help of bacterial biofilms in the bioreactor and are removed by periodical backwashing of the filters which leads to accumulation of PAHs containing sludge. The same sludge samples were stained with the DNA-specific fluorescent dye SybrGreen (Fig. 6). The bacteria were counted microscopically and their cell volumes were determined. Employing the conversion factor of $1.21 \times 10-13 \mathrm{~g}$ of $\mathrm{C}$ $\mu \mathrm{m}^{3}$ (Watson et al. 1977), the amount of bacterial carbon in the sludge tank was found out. For subsequent calculations, it was assumed that microbiological degradation takes place under aerobic conditions only in the bioreactors, and the entry of bacteria from outside to the bioreactors is negligible.

Under aerobic conditions, the assimilation efficiency is estimated to be $50 \%$. So the content of bacterial carbon corresponds to twice the amount of carbon required to form the observed bacterial biomass. This amount is likely to be 
Table 2 Details on sludge volume and bacterial cell mass in few samples

\begin{tabular}{|c|c|c|c|c|c|c|c|c|}
\hline Sample & $\begin{array}{l}\text { Volume } \\
\left(\mu \mathrm{m}^{3}\right)^{\mathrm{a}}\end{array}$ & $\begin{array}{l}\text { Cell count } \\
\text { (cells/gNG) }\end{array}$ & $\begin{array}{l}\text { Oven-dry } \\
\text { mass } \\
\text { (odm)/wet } \\
\text { weight }^{b}\end{array}$ & $\begin{array}{l}\text { Cell count } \\
\text { (cells/g odm) }\end{array}$ & $\begin{array}{l}\text { Bacterial } \\
\text { carbon } \\
(\mathrm{mgCl} / \mathrm{g} \\
\text { odm })^{\mathrm{c}}\end{array}$ & $\begin{array}{l}\text { Carbon required } \\
\text { to form bacterial } \\
\text { carbon }(\mathrm{mgC} / \mathrm{g} \\
\text { odm) }\end{array}$ & $\begin{array}{l}\text { Odm } \\
\text { sludge } \\
(\mathrm{kg})^{\mathrm{d}}\end{array}$ & $\begin{array}{l}\text { Total amount } \\
\text { of biological } \\
\text { extracted } \\
\text { carbon }(\mathrm{g})^{\mathrm{e}}\end{array}$ \\
\hline $\mathrm{BP} / \mathrm{B} 6 / 138 \mathrm{a}$ & $0.79 \pm 0.70$ & $6.3 \times 10^{9}( \pm 1.4)$ & 0.11 & $5.7 \times 10^{10}( \pm 1.3)$ & 6.90 & 13.8 & 880 & 12.144 \\
\hline $\mathrm{BP} / \mathrm{B} 6 / 138 \mathrm{~b}$ & $0.54 \pm 0.40$ & $5.1 \times 10^{9}( \pm 1.2)$ & 0.24 & $2.1 \times 10^{10}( \pm 0.5)$ & 2.54 & 5.08 & 1,920 & 9.754 \\
\hline $\mathrm{BP} / \mathrm{B} 6 / 138 \mathrm{c}$ & $0.65 \pm 0.40$ & $4.9 \times 10^{9}( \pm 1.3)$ & 0.10 & $4.9 \times 10^{10}( \pm 1.3)$ & 5.93 & 11.86 & 800 & 9.488 \\
\hline Mean & 0.66 & 5.4 & 0.15 & 4.2 & 5.10 & 10.25 & 1,200 & 10.462 \\
\hline
\end{tabular}

${ }^{a}$ Mean value based on measurement of 50 individual cells. The relatively high standard deviation reflects the high morphologic diversity of the cells

${ }^{\mathrm{b}}$ Determined by drying $1 \mathrm{~g}$ of sludge overnight at $105^{\circ} \mathrm{C}$

c Determined using the conversation factor $1.21 \times 10^{-13} \mathrm{~g}$ of $\mathrm{C} \mu \mathrm{m}^{-3}$ (see text)

d Based on a total amount of sludge $(8,000 \mathrm{~kg})$

e The mass is seen to be equal to PAHs removed by the bacteria. With respect to the uncertainties in the determination, hydrogen content of the PAHs molecules is negligible against the carbon content (about $95 \mathrm{wt} \%$ )

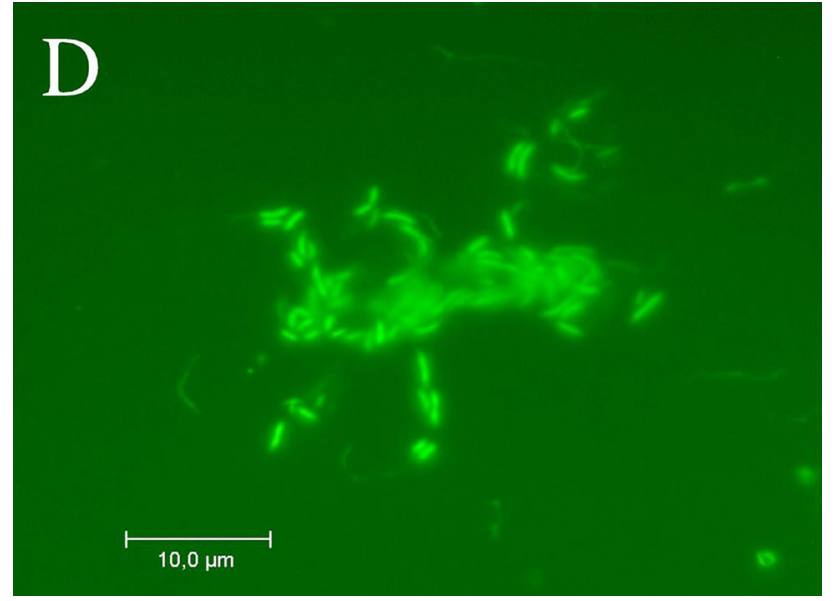

Fig. 6 Bacterial cells from sludge after staining with SYBR GREEN

directly derived from PAHs content of the water. As a result, about $10.4 \mathrm{~kg}$ of PAHs was removed by bacteria. Together with the $820 \mathrm{~g}$ of physically removed PAHs, a total sum of $11.2 \mathrm{~kg}$ of PAHs was removed both by microbiological and physical methods. Table 2 shows details on sludge volume and bacterial cell mass in few samples.

Although several uncertainties have to be considered, there is a difference of about $30 \%$ between the calculated removal of PAHs by using chemical data and flow rates of pumped water $(16 \mathrm{~kg})$ in comparison with the calculated $11.2 \mathrm{~kg}$ removed by microbiological and physical effects.

- One possible explanation for that may be that bacterial biomass is continuously degraded by protozoa. Several sequences of protozoa were found (noted previously) and thus demonstrate the potential constituents of a microbial food chain.

- Another possible reason may be some inefficiency of the incorporation of organic carbon, possibly caused by co-metabolism (so to speak "collateral degradation"). So the accumulation of bacterial biomass could be less efficient despite ongoing biological degradation of the PAHs. Isotopic studies with marked stable C-Isotopes (Jeon et al. 2003), however, showed that a reduction of PAH solely by co-metabolism is unlikely.

- A third possible cause may be that accumulated PAHs in the sludge tank are further degraded under anaerobic conditions. In this case, the assimilation efficiency would be only about $10-20 \%$ in the sludge tank degraded PAHs. Then, the multiplication factor for calculating the organic carbon required to form bacterial carbon would be between 5 and 10 rather than two. Further investigation on different aged sludges will be helpful to estimate the influence of this effect.

Probably all three effects together led to the above stated deviation. To get a more detailed image of the processes leading to PAHs removal in the bioreactors, future investigation should focus on bacterial biofilms to estimate their significance in the degradation process. Isotopic investigations on naphthalene separated from the DNAPL and from the decomposed sludge, however, yielded similar $\delta{ }^{13} \mathrm{C}$ VPDBvalues within the analytical error (DNAPL: $-23.1 \pm 1.0 \%$, sludge: $22.6 \pm 0.9 \%$ ). So no isotopic fractionating due to microbiological degradation could be demonstrated. Further isotopic investigations on PAHs fractionating seem to be meaningless with respect to present analytical possibilities as the most PAHs degraded material (and therefore the material with the greatest possible ${ }^{13} \mathrm{C}$-fractionation) was compared with the least degraded material.

\section{Sorption stage}

Following the microbiological processes, the remaining contaminants are removed by activated carbon filters, 


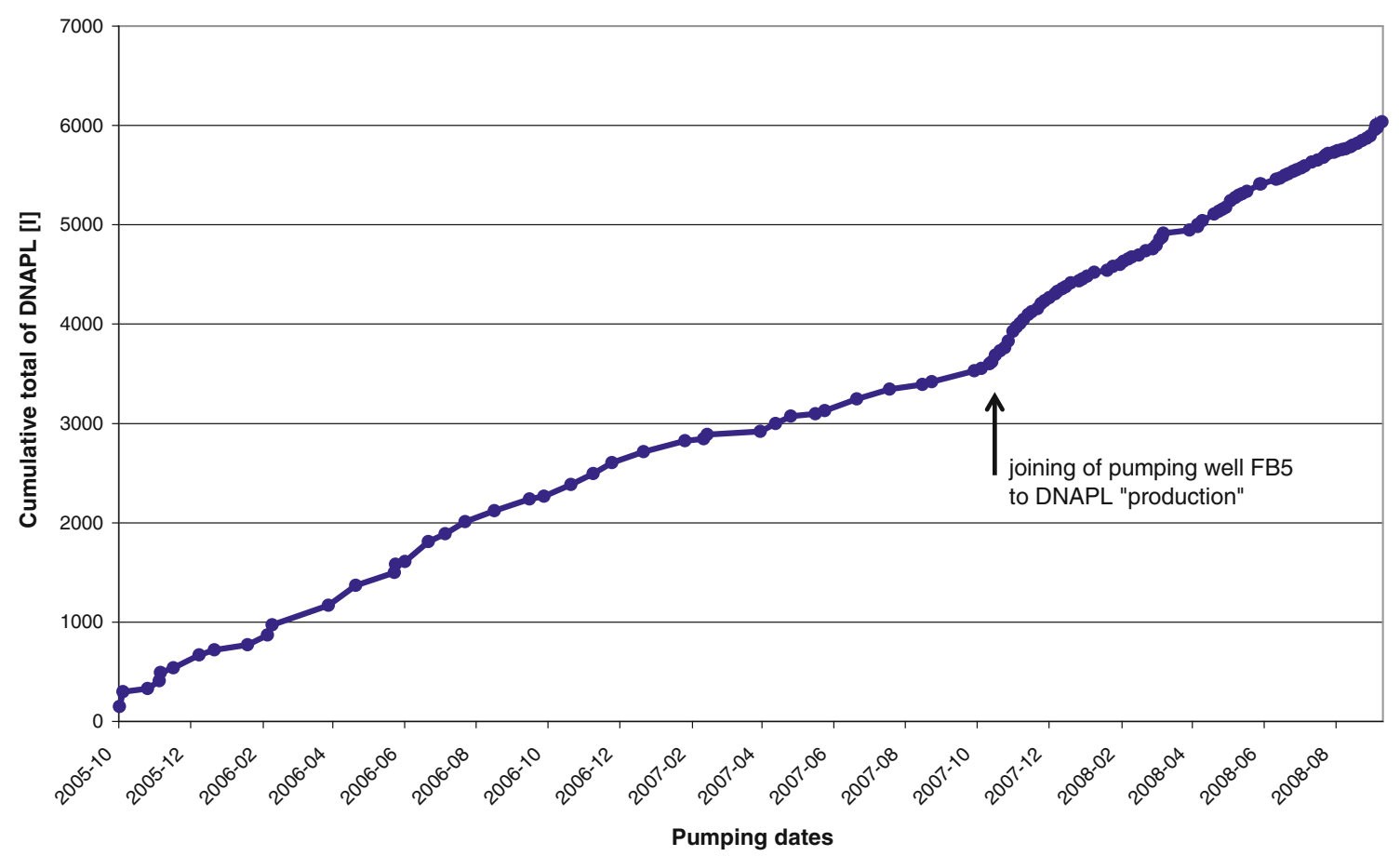

Fig. 7 Cumulative total pumping of DNAPL

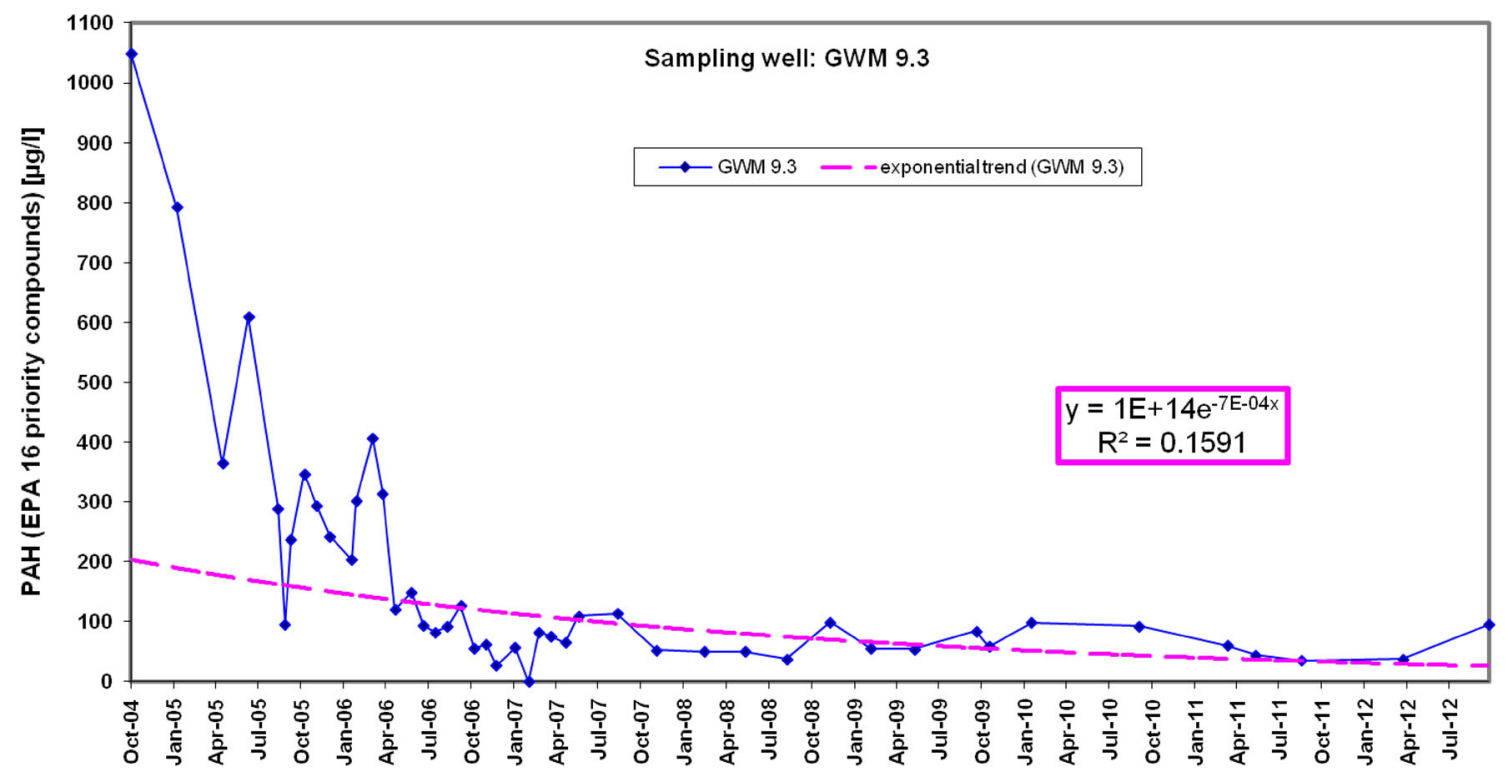

Fig. 8 Concentration of PAHs in downstream observation well GWM 9.3

which ensure the reduction of PAHs in groundwater to less than $0.2 \mu \mathrm{g} / \mathrm{l}$. This quality of treated water after passing through the activated carbon filters almost confirms with the guidelines of German drinking water laws. Only the colony forming units (CFU) is slightly elevated. Due to the design of the treatment plant, $\mathrm{Fe}$ and $\mathrm{Mn}$ contents also are significantly reduced. As most of the DNAPL is removed separately and $90 \%$ of the remaining contaminant is removed in the bioreactors, only a small quantity of activated carbon is required for treatment. Hence, this is a cost-effective method.

Performance evaluation of the remediation plant

Vitte et al. (2011) found that autochthonous bacteria in oil sludge were efficient in degrading PAHs in anoxic/oxic and also in permanent oxic condition. Column studies conducted by Hallberg and Trepte (2003) suggested that $70 \%$ 
reduction of PAHs in contaminated soil is possible by bioremediation. Trably and Patureau (2006) investigated the ability of aerobic microbes to degrade PAHs at different temperature in sewage sludge and found that more than $80 \%$ of the lighter PAHs (fluorene, phenanthrene and anthracene) were removed facilitating safe disposal of the sludge on agricultural lands. USEPA (2001) remediated a creosote-contaminated site which also had dissolved phase PAHs. This pump and treat system (not biological remediation), consisting of 44 wells, extracting about 16.51 of total fluid per minute effectively met the effluent goals by reducing total BNA (base neutral/acid extractable organics that includes PAHs) levels from $6,602 \mu \mathrm{g} / \mathrm{l}$ (prior to the sand filter) to $23.6 \mu \mathrm{g} / \mathrm{l}$.

In the present study, a recovery of $90 \%$ of dissolved PAHs was achieved after more than 3 years of remediation. In addition, 700,000 $\mathrm{m}^{3}$ PAHs-contaminated water with input PAHs concentration of more than $1,000 \mu \mathrm{g} / \mathrm{l}$ was purified to the level of almost drinking water quality (less than $0.2 \mu \mathrm{g} / \mathrm{l}$ ). In the same time span, $7,000 \mathrm{~kg}$ of DNAPL (creosote) was pumped from the bottom of the aquifer separately, and $950 \mathrm{~kg}$ of PAHs (dissolved and emulsified DNAPL) was removed from the groundwater. In the separation stage, $55 \mathrm{~kg}$ of PAHs was recovered. The present study showed that about $90 \%$ of dissolved PAHs was removed from groundwater in the bioreactors due to microbiological and physical sorption effects of the growing and backwashed biomass. The remaining $10 \%$ was removed by activated carbon. In sum, the removal of $7,950 \mathrm{~kg}$ (DNAPL and dissolved PAHs) resulted in only $40 \mathrm{~kg}$ of PAHs having to be removed by adsorption on activated carbon, which is only $0.5 \%$. Hence, the amount of activated carbon needed theoretically for PAHs removal is very small in comparison with the total amount of PAHs removed from the contaminated aquifer.

The performance of this plant discussed in the present study is very efficient when compared to the removal efficiencies of PAHs and polychlorinated biphenyls (PCB) that were assessed in two municipal wastewater treatment plants by Bergqvist et al. (2006). This study showed that for low molecular weight PAHs, the efficiency of removal varied from $84 \%$ to levels at which the compounds were undetectable in the effluents (Sweden), whereas in another site (Lithuania), it ranged between 33 and $95 \%$. Initial treatment performance of a constructed wetland (after air stripping) to remediate groundwater from several contaminants including PAHs was discussed by Rogozinski et al. (1992). Total PAHs excluding naphthalene in the influent ranged from below detection limit (BDL) to $155 \mathrm{ppb}$, whereas PAHs in the effluent after air stripping ranged from BDL to $62 \mathrm{ppb}$ and PAHs concentration in effluent in the wetland was BDL. However, in the present study, $100 \%$ removal by biological and physical methods such as separation and sorption has been achieved when compared to other studies.

The cleaned groundwater is recharged back into the aquifer by the two wells that are situated $600 \mathrm{~m}$ off site. The observation wells on the effluent site show a decrease of up to $95 \%$ of contamination. The development of separate DNAPL pumping is shown in Fig. 7. The concentration of PAHs in the observation well located downstream from the year 2004-2012 is shown in Fig. 8. Thus, this study successfully demonstrated the cost-effective methods developed for remediation of PAHs-contaminated groundwater.

\section{Conclusion}

Bioremediation is one of the most cost-effective techniques to remediate groundwater contaminated with PAHs without much harmful secondary waste being generated. This ex situ method of pumping and treating consists of a series of steps such as separation, biological removal and filtration. In the present case, six pumping wells, two recharge wells and fifteen observation wells were installed in the aquifer. DNAPL and contaminated groundwater is pumped separately. The separator removes the remaining small amounts of DNAPL and more than $90 \%$ of the dissolved PAHs contamination was removed in the bioreactors by both physical and microbiological effects. Naphthalene and methylnaphthalene are reduced by even more than $95 \%$. The indigenous bacteria that facilitated in the reduction of PAH are Zoogloea, Leptothrix, Sphingomonas, Novosphingobium and Comamonadaceae. In the observation period of 5 months, about $15 \mathrm{~kg}$ of PAHs was removed by bacteria and another $820 \mathrm{~g}$ by physical effects. After the microbial process, the reduction of PAHs in groundwater to less than $0.2 \mu \mathrm{g} / \mathrm{l}$ was achieved by activated carbon filters. In sum, the removal of $7,950 \mathrm{~kg}$ PAHs resulted in only $40 \mathrm{~kg}$ PAHs having to be removed by adsorption on activated carbon. This shows that the applied technique fits very well with the contaminated location and hence may be applied to similar sites. The cleaned groundwater was recharged back into the aquifer by two wells situated $600 \mathrm{~m}$ off site. The observation wells on the effluent site show a decrease of up to $95 \%$ of contamination. Thus, this method proved to significantly remediate the PAH contaminated groundwater with the help of indigenous bacteria. The described research is still functioning and further modifications are planned in order to enhance the direct pumping of DNAPL with an additional pumping well. This remediation technique carried can be adopted for cleaning up PAHs-contaminated groundwater in other sites. 
Acknowledgments We thank Jörg Overmann and Martina Mayer (Department of Biology-Microbiology, LMU-München, Munich, Germany) for microbiological investigations, also Jan Jungblut and Erhard Reutter (GEO-data GmbH, Garbsen, Germany) for their contribution and enriching discussion. The second author wishes to thank Mrs. Dagmar Vogel, DB AG Sanierungsmanagement, München, for her great support and supervision. We thank Dr. Brindha Karthikeyan, Research Associate, Anna University for her critical comments and assistance in the preparation of this manuscript.

\section{References}

Abd-Elsalam HE, Hafez EE, Hussain AA, Ali AG, El-Hanafy AA (2009) Isolation and identification of three-rings polyaromatic hydrocarbons (Anthracene and Phenanthrene) degrading bacteria. Am-Eur J Agric Environ Sci 5(1):31-38

Atanassova I, Brummer GW (2004) Polycyclic aromatic hydrocarbons of anthropogenic and biopedogenic origin in a colluviated hydromorphic soil of Western Europe. Geoderma 120:27-34

Bayerisches Geologisches Landesamt (1994) Geologische Übersichtskarte von Bayern 1:1,500,000, Munich

Bergqvist PA, Augulyte L, Jurjoniene V (2006) PAH and PCB removal efficiencies in Umeå (Sweden) and Šiauliai (Lithuania) municipal wastewater treatment plants. Water Air Soil Pollut 175(1-4):291-303

Brassington R (2013) Lessons learned about the nature of groundwater contamination by PAHs: a case history-based discussion. Rem J 23(1):103-121

Chagas-Spinelli ACO, Kato MT, de Lima ES, Gavazza S (2012) Bioremediation of a tropical clay soil contaminated with diesel oil. J Environ Manag 113:510-516

Chen B, Xuan X, Zhu L, Wang J, Gao Y, Yang K, Shen X, Lou B (2004) Distributions of polycyclic aromatic hydrocarbons in surface waters, sediments and soils of Hangzhou City, China. Water Res 38:3558-3568

Commendatore MG, Nievas ML, Amin O, Esteves JL (2012) Sources and distribution of aliphatic and polyaromatic hydrocarbons in coastal sediments from the Ushuaia Bay (Tierra del Fuego, Patagonia, Argentina. Mar Environ Res 74:20-31

Dìez B, Pedròs-Aliò C, Marsh TL, Massana R (2001) Application of denaturing gradient gel electrophoresis (DGGE) to study the diversity of marine picoeukaryotic assemblages and comparison of DGGE with other molecular techniques. Appl Environ Microbiol 67:2942-2951

Fengpeng HE, Zhihuan Z, Yunyang W, Song LU, Liang W, Qingwei BU (2009) Polycyclic aromatic hydrocarbons in soils of Beijing and Tianjin region: vertical distribution, correlation with TOC and transport mechanism. J Environ Sci 21:675-685

Gan S, Lau EV, Ng HK (2009) Remediation of soils contaminated with polycyclic aromatic hydrocarbons (PAHs). J Hazard Mater 172(2-3):532-549

GEO-data GmbH (2003) Standort 6156 Kirchseeon, Sanierungsplanung Abstromsicherung Ost, Garbsen

GEO-data GmbH (2009) Standort 6156 Kirchseeon, Projektphase SD 2; Dokumentation der Betriebsphase Abstromsicherung Ost: 1-3. Betriebsjahr (Textteil und Anlagenband), Garbsen

Guerin TF (2002) A pilot study for the selection of a bioreactor for remediation of groundwater from a coal tar contaminated site. J Hazard Mater 89(2-3):241-252

Hallberg RO, Trepte BS (2003) Bioremediation of PAH polluted soils: column studies. J Soils Sediments 3(1):21-27

Han DM, Tong XX, Jin MG, Hepburn E, Tong CS, Song XF (2013) Evaluation of organic contamination in urban groundwater surrounding a municipal landfill, Zhoukou, China. Environ Monitor Assess 185(4):3413-3444
Harayama S (1997) Polycyclic aromatic hydrocarbon bioremediation design. Curr Opin Biotechnol 8(3):268-273

Haritash AK, Kaushik CP (2009) Biodegradation aspects of polycyclic aromatic hydrocarbons (PAHs): a review. J Hazard Mater 169(1-3):1-15

Hawthorne SB, Grabanski CB (2000) Correlating selective supercritical fluid extraction with bioremediation behaviour of PAHs in a field treatment plot. Environ Sci Technol 34(19):4103-4110

International Maritime Organisation (IMO) (2004) Bioremediation of marine oil spills, p 3

Jeon CO, Park W, Padmanabhan P, DeRito C, Snape JR, Madsen EL (2003) Discovery of a bacterium, with distinctive dioxygenase, that is responsible for in situ biodegradation in contaminated sediment. Proc Natl Acad Sci 100:13591-13596

Kordybach BM, Smreczak B, Pawlas AK (2009) Concentrations, sources, and spatial distribution of individual polycyclic aromatic hydrocarbons (PAHs) in agricultural soils in the Eastern part of the EU: Poland as a case study. Sci Total Environ 407:3746-3753

Li X, Li P, Lin X, Zhang C, Li Q, Gong Z (2008) Biodegradation of aged polycyclic aromatic hydrocarbons (PAHs) by microbial consortia in soil and slurry phases. J Hazard Mater 150(1):21-26

Li J, Shanga X, Zhaoa Z, Tanguaya RL, Donga Q, Huanga C (2010) Polycyclic aromatic hydrocarbons in water, sediment, soil, and plants of the Aojiang River waterway in Wenzhou, China. J Hazard Mater 173(1-3):75-81

Liang Y, Zhang X, Wang J, Li G (2012) Spatial variations of hydrocarbon contamination and soil properties in oil exploring fields across China. J Hazard Mater 241-242:371-378

Limam I, Driss MR (2013) Off-line solid-phase extraction procedure for the determination of polycyclic aromatic hydrocarbons from aqueous matrices. Int J Environ Sci Tech 10(5):973-982

Lladó S, Covino S, Solanas AM, Viñas M, Petruccioli M, D'annibale A (2013) Comparative assessment of bioremediation approaches to highly recalcitrant $\mathrm{PAH}$ degradation in a real industrial polluted soil. J Hazard Mater. doi:10.1016/j.jhazmat.2013.01. 020

Lors C, Damidot D, Ponge JF, Périé F (2012) Comparison of a bioremediation process of PAHs in a PAH-contaminated soil at field and laboratory scales. Environ Pollut 165:11-17

Mao J, Luo Y, Teng Y, Li Z (2012) Bioremediation of polycyclic aromatic hydrocarbon-contaminated soil by a bacterial consortium and associated microbial community changes. Int Biodeterioration Biodegradation 70:141-147

Menendez-Vega D, Gallego JLR, Pelaez AI, de Cordoba GF, Moreno J, Muñoz D, Sanchez J (2007) Engineered in situ bioremediation of soil and groundwater polluted with weathered hydrocarbons. Eur J Soil Biol 43(5-6):310-321

Menzie CA, Potokib B (1992) Exposure to carcinogenic PAHs in the environment. Environ Sci Technol 26:1278-1284

Miguel VS, Peinado C, Catalina F, Abrusci C (2009) Bioremediation of naphthalene in water by Sphingomonas paucimobilis using new biodegradable surfactants based on poly (-caprolactone). Int Biodeterioration Biodegradation 63(2):217-223

Moscoso F, Teijiz I, Deive FJ, Sanromán MA (2012) Efficient PAHs biodegradation by a bacterial consortium at flask and bioreactor scale. Bioresource Techn 119:270-276

Muangchinda C, Pansri R, Wongwongsee W, Pinyakong O (2013) Assessment of polycyclic aromatic hydrocarbon biodegradation potential in mangrove sediment from Don Hoi Lot, Samut Songkram Province, Thailand. J Appl Microbiol. doi:10.1111/ jam. 12128

Muyzer G, Hottenträger S, Teske A, Waver C (1995) Denaturing gradient gel electrophoresis of PCR-amplified 16S rDNA-a new molecular approach to analyse the genetic diversity of mixed microbial communities, In: Akkermans ADL, van Elsas 
JD, de Bruijn FJ (eds) Molecular microbial ecology manual, 2nd ed. Kluwer, Dordrecht, pp 3.4.4.1-3.4.4.22

Neuhauser EF, Ripp JA, Azzolina NA, Madsen EL, Mauro DM, Taylor T (2009) Monitored natural attenuation of manufactured gas plant tar mono and polycyclic aromatic hydrocarbons in ground water: a 14-Year Field Study. Ground Water Monit Rem 29(3):66-76

Pandey PK, Patel KS, Lenicek J (1999) Polycyclic aromatic hydrocarbons: need for assessment of health risks in India? Study of an urban-industrial location in India. Environ Monit Assess 59:287-319

Penet S, Marchal R, Sghir A, Monot F (2004) Biodegradation of hydrocarbon cuts used for diesel oil formulation. Appl Microbiol Biotechnol 66:40-47

Rogozinski LR, Laubaucher RC, Farmer JM (1992) Groundwater treatment via constructed wetlands. Presented at the petroleum hydrocarbons conference, November 4-6, 1992, Houston

Seo Y, Jang A, Bishop PL (2007) Organic mulch biowall for PAH contaminated groundwater remediation. Eur J Soil Biol 43(5-6):304-309

Silva-Castro GA, Rodelas B, Perucha C, Laguna J, González-López J, Calvo C (2013) Bioremediation of diesel-polluted soil using biostimulation as post-treatment after oxidation with Fenton-like reagents: assays in a pilot plant. Sci Total Environ 445-446:347-355

Thavamani P, Megharaj M, Naidu R (2012) Multivariate analysis of mixed contaminants (PAHs and heavy metals) at manufactured gas plant site soils. Environ Monit Assess 184(6):3875-3885

Trably E, Patureau D (2006) Successful treatment of low PAHcontaminated sewage sludge in aerobic bioreactors. Environ Sci Pollut Res Int 13(3):170-176

USEPA (2001) Report of the remediation system evaluation (document no. EPA 542-R-02-008f). pp 1-25. Available from; www. epa.gov/tio or www.cluin.org/rse. Accessed on 16th July 2011

Valderrama C, Gamisans X, Cortina JL, Farrán A, De las Heras FX (2009) Evaluation of polyaromatic hydrocarbon removal from aqueous solutions using activated carbon and hyper-crosslinked polymer (Macronet MN200). J Chem Technol Biotechnol $84: 236-245$

Vázquez S, Nogales B, Ruberto L, Mestre C, Christie-Oleza J, Ferrero M, Bosch R, Mac Cormack WP (2013) Characterization of bacterial consortia from diesel-contaminated Antarctic soils: towards the design of tailored formulas for bioaugmentation. Int Biodeterioration Biodegradation 77:22-30

Vitte I, Duran R, Jézéquel R, Caumette P, Cravo-Laureau C (2011) Effect of oxic/anoxic switches on bacterial communities and $\mathrm{PAH}$ biodegradation in an oil-contaminated sludge. Environ Sci Pollut Res 18(6):1022-1032

Wang X, Yu X, Bartha R (1990) Effect of bioremediation on polycyclic aromatic hydrocarbon residues in soil. Environ Sci Technol 24(7):1086-1089

Watson SW, Novitsky TJ, Quinby HL, Valois FW (1977) Determination of bacterial number and biomass in the marine environment. Appl Environ Microbiol 33:940-946

Yagi JM, Neuhauser EF, Ripp JA, Mauro DM, Madsen EL (2010) Subsurface ecosystem resilience: long-term attenuation of subsurface contaminants supports a dynamic microbial community. ISME J 4(1):131-143

Zhang H, Kallimanis A, Koukkou AI, Drainas C (2004) Isolation and characterization of novel bacteria degrading polycyclic aromatic hydrocarbons from polluted Greek soils. Appl Microbiol Biotechnol 65:124-131

Zhang J, Dai J, Chen H, Du X, Wang W, Wang R (2012) Petroleum contamination in groundwater/air and its effects on farmland soil in the outskirt of an industrial city in China. J Geochem Explor 118:19-29

Zhu L, Chen Y, Zhou R (2008) Distribution of polycyclic aromatic hydrocarbons in water, sediment and soil in drinking water resource of Zhejiang Province, China. J Hazard Mater 150:308-316 